\title{
VARIABILITY OF MOLECULAR GENETIC STRUCTURE IN CODLING MOTH Cydia pomonella (L.) POPULATIONS UNDER THE INFLUENCE OF INSECTICIDES AND ENVIRONMENTAL STRESSES
}

\author{
V.I. Kil', E.N. Besedina \\ All-Russia Research and Development Institute of Biological Plant Protection, RAAS, Krasnodar 350039, Russia \\ e-mail:vlkil@inbox.ru
}

Received September 19, 2011

S u m m a r y

The results of the PCR analysis of two codling moth populations using RAPD and SSR markers are presented. The molecular genetic structure of investigated pest populations is described and its variability under influence of insecticides, varying climatic conditions during 2008 to 2011 and geographic location is studied. The intra-population genetic diversity by two microsatellite loci was estimated in pests from the gardens with different insecticide press. Genetic diversity of codling moth populations was shown to depend mainly on genetic features of the populations, bur not on the insecticide load or weather conditions.

Keywords: polymorphism, genetic diversity, microsatellite loci, population, codling moth, DNA, RAPD-PCR, SSR-PCR.

Population genetics of insect pests is an important aspect of monitoring of pests' migrations and gene flow $(1,2)$. The study of changes in molecular-genetic structure of pest populations is the way to reveal mechanisms of their insecticide resistance (3).

Codling moth Cydia pomonella (L.) (Lepidoptera: Tortricidae) is the main pest of fruit orchards in the world that causes a considerable economic damage. This pest is the target of more than $70 \%$ insecticide treatments in pest control of fruit crops (4). However, it is still a very few data on variability of genetic structure of codling moth and genetic diversity of its populations under insecticide load. At the same time, such information is important for planning the strategy of crop protection (5).

Previously, the authors investigated the molecular genetic structure of codling moth in different geographical populations using RAPD, ISSR, and SSR markers (6-9) .

The purpose of this work was studying the effects of insecticides, geographical location, and climatic conditions of the year on molecular-genetic structure and genetic diversity in populations of Cydia pomonella.

Technique. The objects of observations were two populations of codling moth (Krasnodar Krai, 2008-2010). The insects were collected with pheromone traps in orchards grown under unequal intensity of insecticide treatment: Krasnodar population - in orchards of the All-Russia Research and Development Institute of Biological Plant Protection (VNIIBZR, up to 12 treatments per year), experimental station "Ecological Garden" (4-5 treatments with insecticides of low environmental risk), and experimental station "Organic garden" (without treatment); Yeysk population - in orchards of "College Yeysky" (up to 12 treatments annually) and "Malus" (without treatment). Each sample included 20-60 insects.

Isolation of DNA, RAPD, and SSR-PCR were performed under the protocols described previously (10, 11). To avoid experimental errors in RAPD-PCR, all DNA samples were analyzed simultaneously in a single reaction (separately for each primer) on the same device using a standard reagent kit. Earlier such conditions of RAPD-PCR were sufficient for an adequate assessment of results, including the analysis of DNA of insects from different taxa (12). In SSR-PCR were used two pairs of primers (13) flanking microsatellite loci: Sr1.63 - motif of the repeat $(\mathrm{GA})_{19}, \mathrm{Cp} 2.39$ - motif of the repeat (TC) ${ }_{4} \mathrm{AC}(\mathrm{TC})_{11}$. The products of SSR-PCR were separated in $8 \%$ polyacrylamide gel of $20 \mathrm{~cm}$ length and $1 \mathrm{~mm}$ thickness at a voltage of 200-300 volts for 5-6 hours. The amplicons were stained with ethidium bromide and visualized in UV light on trans-illuminator ECX-20.M ("Vilber Lourmat", France).

The degree of DNA polymorphism was determined as the ratio: number of polymorphic DNA fragments / total number of DNA markers. Molecular-genetic structure was assessed by the frequency of DNA fragments, along with comparative evaluation of variation with $\chi^{2}$ criterion. Comparison of sample means was performed using Student's $t$-test in Microsoft Excel. Genetic diversity of populations, genetic similarity, and cluster analysis of the data were assessed by UPGMA (unweighted pair-group method with arithmetic mean) according to Nei and Shannon in the program POPGENE v. 1.31.

Results. Effects of insecticides on genetic diversity of pest populations. Results of SSR-PCR test revealed the absence of significant differences in DNA-spectra of codling moth from Krasnodar population (Fig. 1), which was clearly supported by statistical treatment of the data (Table 1).

1. DNA-polymorphism on SSR-markers and genetic diversity in populations of Cydia pomonella (L.) in orchards with different intensity of insecticide treatment (Krasnodar Krai, 2010)

\begin{tabular}{|c|c|c|c|c|c|}
\hline \multirow[b]{2}{*}{ Index } & \multicolumn{3}{|c|}{ Krasnodar population } & \multicolumn{2}{|c|}{ Yeysk population } \\
\hline & $\begin{array}{l}\text { experimental sta- } \\
\text { tion "Organic gar- } \\
\text { den" } \\
\text { (without treatment) }\end{array}$ & $\begin{array}{c}\text { experimental sta- } \\
\text { tion "Ecological } \\
\text { garden" }\end{array}$ & VNIIBRZ & $\begin{array}{l}\text { orchard "Malus" } \\
\text { (without treatment) }\end{array}$ & $\begin{array}{l}\text { orchard "College } \\
\text { Yeysky" }\end{array}$ \\
\hline \multicolumn{6}{|c|}{ L o c u s Cp.1.63 } \\
\hline $\mathrm{h}$ & $0,14 \pm 0,17$ & $0,14 \pm 0,16$ & $0,17 \pm 0,14^{*}$ & $0,08 \pm 0,09$ & $0,08 \pm 0,06$ \\
\hline I & $0,23 \pm 0,23$ & $0,22 \pm 0,23$ & $0,29 \pm 0,18^{*}$ & $0,15 \pm 0,17$ & $0,15 \pm 0,11$ \\
\hline \multicolumn{6}{|c|}{ L o c u s Cp. 2.39} \\
\hline $\mathrm{h}$ & $0,22 \pm 0,15^{*}$ & $0,25 \pm 0,14^{*}$ & $0,22 \pm 0,17^{*}$ & $0,17 \pm 0,11$ & $0,12 \pm 0,10$ \\
\hline I & $0,35 \pm 0,19^{*}$ & $0,40 \pm 0,19^{*}$ & $0,35 \pm 0,24 *$ & $0,30 \pm 0,16$ & $0,22 \pm 0,15$ \\
\hline
\end{tabular}
ments against insect pests annually; orchards of the experimental station "Ecological garden" and "College Yeysky" - respectively, 4-5 and up to 12 treatments against insect pests annually; $\mathrm{h}$ - Nei's genetic diversity (average \pm standard deviation), I Shannon index (average \pm standard deviation).

* Reliably differs from the sample of "College Yeysky" orchard $\left(t_{\text {fact. }} \geq t_{05}\right)$. 
Studying the impact of insecticide treatments on intrapopulation genetic polymorphism of codling moth, it was found that in both populations of Krasnodar and Yeysk the indices of genetic diversity in the non-treated orchards didn't differ from those of the treated ones, i.e. the differences were statistically insignificant. Even heavy insecticide load (in orchards of VNIIBZR and "College Yeysky" - up to 12 treatments per year) didn't reduce intrapopulation genetic diversity of the pest (Table 1).

A

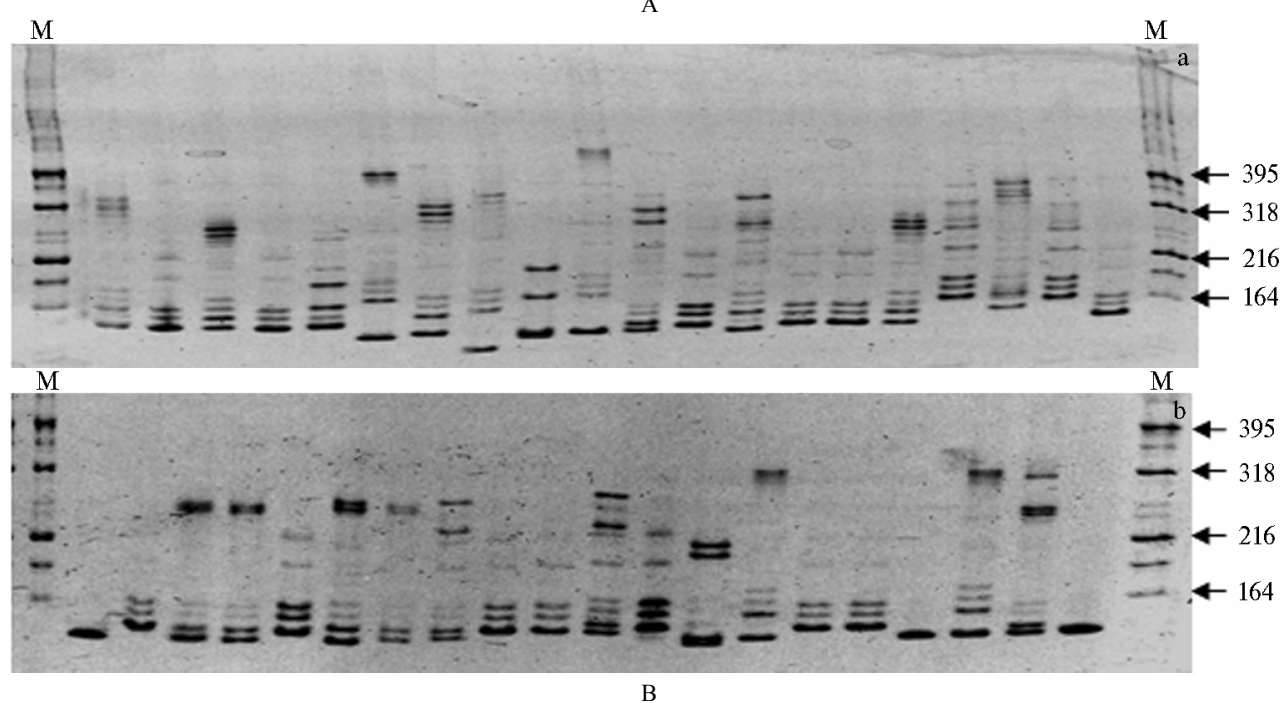

B

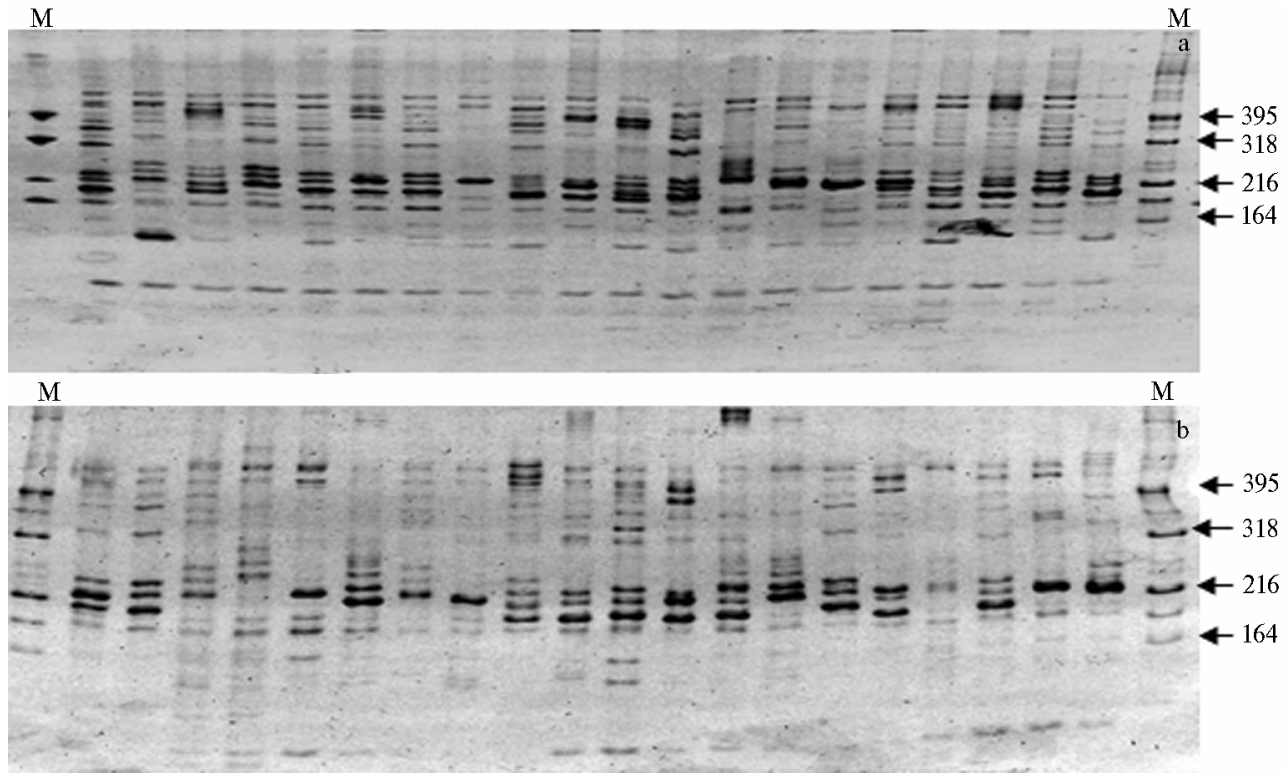

Fig. 1. Individual electrophoregrams of amplicons (SSR-PCR) for microsatellite loci Cp1.63 (A) and Cp2.39 (B) in Cydia pomonella (L.) Krasnodar population collected in orchards with intense insecticide treatment (a - All-Russia Research and Development Institute of Biological Plant Protection, up to 12 treatments against insect pests annually) and without the treatment ( $b$ - experimental station "Organic garden")

$\mathrm{M}$ - molecular weight marker, bp (8\% polyacrylamide gel) (Krasnodar Krai, 2010).

At the same time, a comparison of the two studied geographic populations of codling moth revealed reliable differences most significant for the locus Cp.2.39 (Table 1): genetic diversity in Krasnodar population of C. pomonella was 1,5-2,0 times higher than in Yeysk population (in general over all samples $t_{\text {fact. }}=3,69 \geq t_{05}$ ). This indicates the fact that intrapopulation genetic diversity depends mainly on geographic location of population (its biological and genotypic features associated with many factors including gene flow), while insecticide treatment doesn't reduce genetic diversity in populations (which was previously assumed as possible) $(8,9)$.

This conclusion was confirmed by evaluation of genetic similarity of the studied samples. The highest genetic similarity was observed in samples obtained from Yeysk orchards "College Yeysky" and "Malus" (Nei's genetic identity I = 1,00), which allows assuming them as one population. The two samples of Krasnodar population were also genetically similar $(i=0,94-0,96)$ and they different from the samples of Yeisk population. These facts were clearly reflected by cluster analysis (Fig. 2): the studied samples form two separate clusters corresponding to their geographical location. 


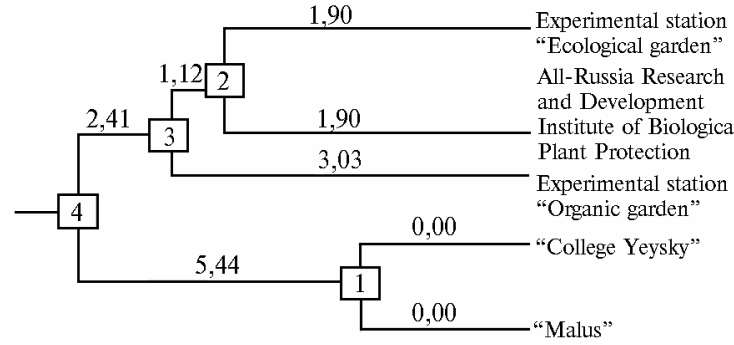

Fig. 2. Dendrogram of genetic differences between populations of Cydia pomonella (L.) in orchards of Yeysk (1) and Krasnodar Krai (2 and 3) with unequal intensity of insecticide treatment пуляциями (4) (see "Technique"). Constructed according to M. Nei by UPGMA (Krasnodar Krai, 2010).
So, intrapopulation genetic diversity of codling moth was independent on number of insecticide treatments in orchards. Insecticides certainly affect not only population size, but also molecular-genetic structure of pest populations, i.e., frequency of specific genetic elements. However, such effect didn't change intra-population genetic diversity of codling moth, and the observed differences in this character were associated only with geographical location of populations (their genotypic characteristics and conditions of reproduction ).

These findings were consistent with conclusions of German scientists (14) who studied the resistance of codling moth to baculovirus CpGV: even at high indices of resistance the pest population remained genetically heterogeneous and included individuals sensitive to the virus. Therefore, susceptible and resistant populations of insect pests may have similar genetic diversity due to heterogeneity of the resistant populations.

Effects of climatic conditions of the year on molecular-genetic structure and genetic diversity of pest populations. The effects caused by environmental conditions to molecular-genetic structure of pest populations were assessed using the samples of insects collected in one orchard (VNIIBZR) in different years of study (2008 and 2010 ). In both these years, the orchard was exposed to a similar insecticide load, but the summer of 2010 was extremely hot (over $40{ }^{\circ} \mathrm{C}$ ) with almost no rain.

According to results of RAPD-PCR of C. pomonella Krasnodar population, DNA-spectra of the two studied samples (2008 and 2010) showed the absence of any significant differences. At the same time, in some cases (for individual primers) there was found an unequal frequency of certain DNA markers. Along with it, the sample of 2008 contained a slightly less number of DNA fragments per individual compared to that of 2010 (Table 2). Probably, this was caused by partial degradation of aqueous solutions of DNA stored for 2 years (since 2008) at $-20{ }^{\circ} \mathrm{C}$. However, the molecular-genetic structure remained generally unchanged with no statistically significant differences in DNA spectra $\left(\chi_{\text {fact. }}^{2} \leq \chi_{05}^{2}\right)$.

\section{DNA-polymorphism for RAPD-markers in Krasnodar population of Cydia pomonella} (L.) against the intense insecticide load in different years of study (Krasnodar Krai, orchard of the All-Russia Research and Development Institute of Biological Plant Protection)

\begin{tabular}{|c|c|c|c|c|c|c|c|}
\hline \multirow[t]{2}{*}{ RAPD-primer } & \multicolumn{2}{|c|}{$\begin{array}{l}\text { Degree of DNA- } \\
\text { polymorphism, } \%\end{array}$} & \multicolumn{2}{|c|}{$\begin{array}{l}\text { Number of detected } \\
\text { DNA-fragments }\end{array}$} & \multicolumn{2}{|c|}{$\begin{array}{l}\text { Average number of DNA- } \\
\text { fragments per individual }\end{array}$} & \multirow[t]{2}{*}{$\chi^{2}$} \\
\hline & 2008 & 2010 & 2008 & 2010 & 2008 & 2010 & \\
\hline OPA02 & 100 & 100 & 19 & 18 & 5,9 & 7,5 & 8,4 \\
\hline OPA06 & 100 & 100 & 15 & 16 & 4,4 & 7,8 & 21,2 \\
\hline OPA20 & 94,7 & 94,7 & 19 & 19 & 4,5 & 6,9 & 25,2 \\
\hline OPB01 & 100 & 100 & 17 & 16 & 4,9 & 5,2 & 17,2 \\
\hline OPB08 & 94,1 & 94,1 & 12 & 17 & 4,3 & 5,3 & 12,8 \\
\hline OPD06 & 100 & 100 & 11 & 15 & 4,0 & 5,9 & 18,2 \\
\hline OPE07 & 100 & 94,1 & 17 & 17 & 5,3 & 7,4 & 22,5 \\
\hline
\end{tabular}

In order to test the assumption about a partial degradation of DNA, it was conducted RAPD-analysis of Yeisk population with two primers - ORA06 and ORA20: the samples of DNA stored at $-20{ }^{\circ} \mathrm{C}$ for 2 years were compared with the samples freshly (2011) derived from the same biomaterial of 2008 (insects stored in Petri dishes at $+4{ }^{\circ} \mathrm{C}$ ). In the variant of PCR with DNA stored at $20{ }^{\circ} \mathrm{C}$, amplicons obtained for RAPD-primer OPA06 were weekly expressed or absent, while for RAPD-primer OPA20 there was a reliably less number of DNA-fragments than in the variant with freshly derived DNA (in average per individual - respectively, $8,7 \pm 0,92$ vs. $\left.14,2 \pm 0,78, t_{\text {fact. }}=4,59 \geq t_{05}\right)$.

3. DNA-polymorphism on SSR-markers and genetic diversity in populations of Cydia pomonella $(\mathrm{L}$.$) against the intense insecticide load in different years of study (Krasno-$ dar Krai)

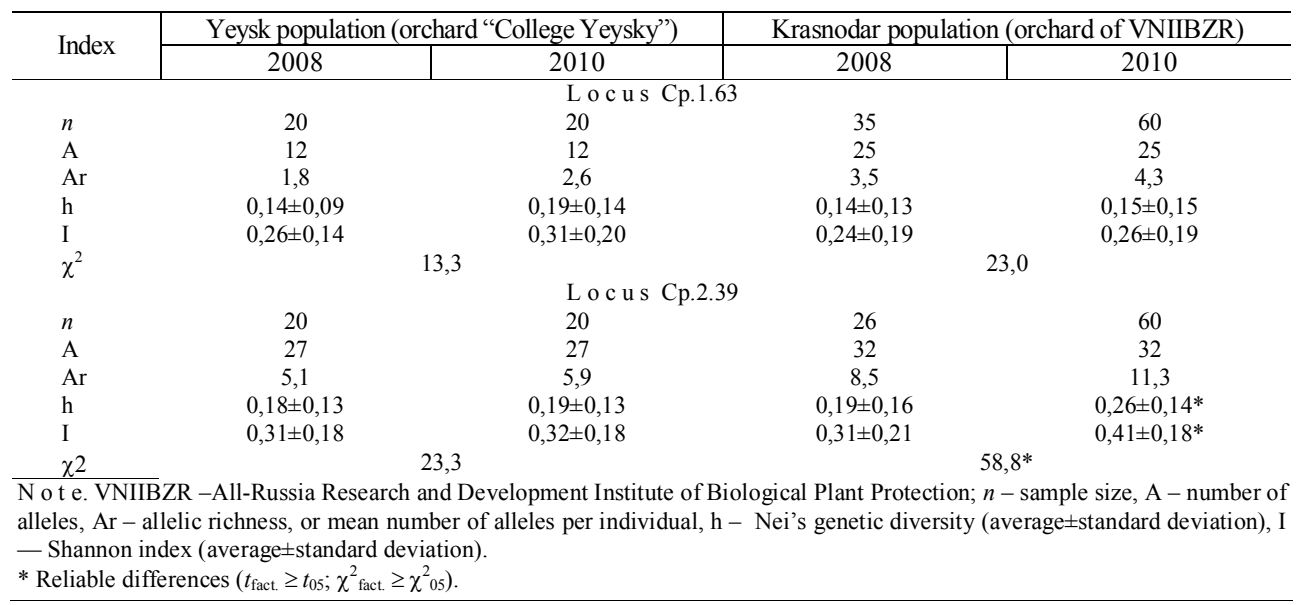

This fact means that the detected changes in molecular-genetic structure of studied populations were most likely associated with degradation of aqueous solutions of DNA during storage and not by effects of external environment.

In contrast to RAPD-markers, microsatellite SSR-markers provide better reproducibility of results due to a higher 
temperature of PCR annealing and higher specificity of binding primers to DNA matrix. That's why microsatellites can be quite informative about changes in molecular-genetic structure of pest populations caused by climatic conditions of the year. According to results of SSR-PCR, electrophoretic spectra of DNA amplicons of the insects collected in 2010 included more fragments compared to those of 2008 (Table 3). In Krasnodar populations of $C$. pomonella such changes of molecular-genetic structure and genetic diversity (for locus Cp.2.39) were statistically significant $\left(t_{\text {fact. }} \geq t_{05} ; \chi_{\text {fact. }}^{2} \geq \chi_{05}^{2}\right.$ ). Along with it, DNA samples of the year 2008 exhibited a sligt decrease in average number of DNA fragments per individual, as well as lower intra-population genetic diversity compared with those of 2010 .

So, testing populations of C. pomonella by both RAPD- and SSR-markers (despite the higher specificity of binding) revealed general reduce in number of DNA-markers in PCR-spectra of DNA samples isolated in 2008. The authors assume it as a result of partial degradation of aqueous solutions of DNA (samples of 2008) after a 2-year storage at for 2 years at $-20{ }^{\circ} \mathrm{C}$, not linked to changes in molecular-genetic structure of populations. Consequently, hot and dry summer of the year 2010 and insecticide load didn't cause a destructive effect on intrapopulation genetic diversity of codling moth.

So, insecticide load and conditions of the year didn't reduce genetic diversity in populations of codling moth Cydia pomonella (L.); differences in this character found in the two studied populations were caused mainly by their geographical location (genetic features). Environmental stress factors, such as insecticides or extreme weather conditions, may affect population size of $C$. pomonella or molecular-genetic structure of populations, eg. frequency of particular genotypes. However, it was experimentally proved that such changes not mandatorily mean the reduce of intrapopulation genetic diversity of individuals. The important fact about comparative PCR-analysis of various samples of insects is the possibility of partial degradation of aqueous solutions of isolated total DNA (eg., due to defrosting at emergency power cutoff). Such changes inevitably lead to the decrease in number of DNA fragments in PCR-spectra (RAPD- and SSR-PCR). In this regard, the authors recommend to store insect biomaterial in Petri dishes at $+4{ }^{\circ} \mathrm{C}$, and for aqueous DNA preparations - to lyophilize or re-precipitate with ethanol and store in a freezer (at - $\left.20{ }^{\circ} \mathrm{C}\right)$.

Authors express a sincere gratitude to O.D. Niyazov and E.S. Sugonyaev who provided biological material for the analysis.

\section{REFERENCES}

1. Scott L.J., Lawrence N., Lange C.L. et al. Population dynamics and gene flow of Helicoverpa armigera (Lepidoptera: Noctuidae) on cotton and grain crops in the Murrumbidgee Valley, Australia. J. Econ. Entomol., 2006, 99: 155-163.

2. Endersby N.M., Hoffmann A.A., McKechnie S.W., Weeks A.R.Is there genetic structure in populations of Helicoverpa armigera from Australia? Entomol. Exp. Appl., 2007, 122: 253-263.

3. Timm A.E., Geertsema H., Warnich L. Gene flow among Cydia pomonella (L.) (Lepidoptera: Tortricidae) geographic and host populations in South Africa. J. Econ. Entomol., 2006, 99: 341-348.

4. Franck P., Reyes M., Olivares J., Sauphanor B. Genetic architecture in codling moth populations: comparison between microsatellite and insecticide resistance markers. Mol. Ecol., 2007, 16: 3554-3564.

5. Calkins C.O., Faust R.J. Overview of areawide programs and the program for suppression of codling moth in the western USA directed by the United States Department of Agriculture - Agricultural Research Service. Pest. Manag. Sci., 2003, 59: 601-604.

6. Kil' V.I., Besedina E.N., Fedicheva O.O. Trudy Stavropol'skogo otdeleniya Russkogo entomologicheskogo obshchestva (materialy II Mezhdunarodnoi nauchnoprakticheskoi internet-konferentsii «Aktual'nye voprosy entomologii») [Sci. Works of the Stavropol' Department of Russian Entomological Society. Proc. II Int. Sci.Pract. Internet Conf. «Live Issues of Entomology»], 2009, 5: 154-157.

7. Kil' V.I., Besedina E.N., Fedicheva O.O. Informatsionnyi byulleten' Vostochno-Palearkticheskoi regional'noi sektsii Mezhdunarodnoi organizatsii po biologicheskoi bor'be s vrednymi zhivotnymi i rasteniyami (materialy dokladov Mezhdunarodnogo simpoziuma "Zashchita rastenii - dostizheniva i perspektivy», g. Kishinev) [Inf. Bull. of the East-Palearctic Regional Department of the International Organization for Biological Control of Pest Animals and Plants. Proc. Int. Symp. «Crop Protection - Achievments and Prospects»], 2009, 40: 92-94.

8. Kil' V.I. Materialy Mezhdunarodnoi nauchno-prakticheskoi konferentsii «Biologicheskaya zashchita rastenii - osnova stabilizatsii agroekosistem» [Proc. Int. Sci.Pract. Conf. «Biological Crop Protection - A Basis of Sustainable Agroecosystems»]. Krasnodar, 2010, v. 6: $281-284$.

9. Kil' V.I. Politematicheskii setevoi elektronnyi nauchnyi zhurnal Kubanskogo gosudarstvennogo universiteta [Multitopic Scientific Electronic Network Magazine of Kuban State University], 2010, 62(08), oktyabr' (http://ej.kubagro.ru/2010/08/pdf).

10. Kil' V.I. Metodika otsenki DNK-polimorfizma populyatsii nasekomykh s pomoshch'yu PTSR (RAPD-i ISSR-PCR): metodicheskie rekomendatsii [The Method for Evaluating DNA Polymorphism in Insect Populations Using RAPD- and ISSR-PCR: Guidelines]. Krasnodar, 2009.

11. Kil' V.I. Politematicheskii setevoi elektronnyi nauchnyi zhurnal Kubanskogo gosudarstvennogo universiteta [Multitopic Scientific Electronic Network Magazine of Kuban State University], 2011, 68(04), aprel' (http://ej.kubag-ro.ru/2011/04/pdf).

12. Kil' V.I., Gronin V.V., Krutenko D.V., Ismailov V.Ya. Sel'skokhozyaistvennaya Biologiya [Agricultural Biology], 2008, 1: 70-76.

13. Franck P., Guérin F., Loiseau A., Sauphanor B.Isolation and characterization of microsatellite loci in the codling moth Cydia pomonella L. (Lepidoptera, Tortricidae). Molecular Biology Notes, 2005, 5(1): 99-102.

14. Asser-Kaiser S., Fritsch E., Undorf-Spahn K., Kienzle J., Eberle K.E., Gund N.A., Reineke A., Zebitz C.P.W., Heckel D.G., Huber J., Jehle J.A. Rapid emergence of Baculovirus resistance in codling moth due to dominant sex linked inheritance. Science, 2007, 317: 1916-1918. 